\title{
Developing Physics Digital Literacy Skill Diagnostic Test Assisted by Google Form for Senior High School Students
}

\author{
Nurhasanah ${ }^{1,{ }^{*}}$ Supahar ${ }^{2,}$ Erlita Agustina ${ }^{1,}$ Syarifah Aini Nabila ${ }^{1,}$ Puji Rahayu ${ }^{3}$ \\ ${ }^{I}$ Master of Physics Education, Faculty of Mathematics and Natural Sciences, Universitas Negeri Yogyakarta, \\ Indonesia \\ ${ }^{2}$ Department of Physics Education, Faculty of Mathematics and Natural Sciences, Universitas Negeri \\ Yogyakarta, Indonesia \\ ${ }^{3}$ Master of Science Education, Faculty of Mathematics and Natural Sciences, Universitas Negeri Yogyakarta, \\ Indonesia \\ *Corresponding author. Email: nurhasanah.2019@student.uny.ac.id
}

\begin{abstract}
This research aimed to develop a test instrument in identifying digital literacy skills in high school physics learning. This study used instrument development model by Mardapi. The data method used a digital literacy test via Google Form. The research was conducted at SMAN 1 Prambanan Klaten, Central Java, involving 30 students of class XI MIPA program. Analysis of the content validity used the Aiken V. The dichotomous item analysis used the 1parameter Logistic Model (1 PL) or Rasch model. The instrument developed to measure digital literacy skills is declared valid and suitable for use. The digital literacy instrument assisted by Google Form has met the expert validation with high validity. Ten items were developed, item 1 has a low difficulty level, so the item is too easy and not good to use. While the other 9 items have a good difficulty level and can be used.
\end{abstract}

Keywords: Instrument, Digital literacy skill, Physics assessment.

\section{INTRODUCTION}

Strengthening and developing character and literacy activities are important things for the progress of the country to live the life in the era of globalization. In order to make Indonesia's development successful in the 21 st century, it is a must for Indonesians to master literacy skills. One of the literacy skills that must be mastered is digital literacy [1]. The need for students today to be digitally literate is increasing, and educational organizations around the world have responded with new curricula to teach digital literacy skills [2].

It is difficult to give a precise definition of "digital literacy" because this term has been used with various meanings in the literature. Digital literacy, media literacy, Information Literacy 2.0, and ICT literacy have been "linked" to many reports on community development and education [3]. Digital literacy includes the ability or skills to plan, implement, or evaluate digital actions in solving daily work as well as the ability to reflect jobs [4].
The European Commission's Digital Competency Framework 2.1, which is structured dimensionally, and includes 5 components of digital competence, including: information and data literacy, communication and collaboration, digital content creation, security, and problem solving [5]. Information literacy refers to the mastery of knowledge needed to collect, synthesize, analyze, interpret, and evaluate information, and the proper attitude to information processing with a rational understanding behind the use of information [6].

Digital literacy as the ability to use, understand evaluation of technology, and also understand the principles and technology strategies needed to realize specific goals and develop solutions [7]. Information and computer literacy refers to the ability of an individual to use a computer, to investigate, create, and communicate to participate effectively at home, school, office or work, or in society [8]. Five disciplinary frameworks that can be adopted to assess and measure the conceptual components of digital literacy include: information literacy, computer 
literacy or ICT, media literacy, communication literacy, and technology literacy [9]. Digital literacy as a life skill needed to fully participate in our society that full of information and media.

The growth of the digital environment encourages the use of digital resources and communication tools in school education [6]. Digital literacy teaches someone to be able to operate digital technology and think critically about the information received [10]. Digital literacy is very much needed in living in today's technological era. However, the rapid penetration of various digital applications and social media has not been followed by a high level of digital literacy skills. This is crucial to pay attention to, especially in relation to the various negative impacts that digital technology can cause [11].

Assessment is an important aspect of learning activities. An effort to improve the quality of teaching and learning can be pursued through quality improvement in the assessment system [12]. Assessment activities must be able to help students achieve optimal learning development and be able to provide information to teachers in improving their teaching abilities [13]. Therefore, the assessment instrument carried out must be able to assess student skills appropriately and well. In the implementation of learning, the diagnostic test is a type of formative test that is carried out during the series of learning processes [14]. In this situation, through a diagnostic test, the teacher can apply the principles of assessment as learning as a process of developing and supporting the strengthening of the knowledge and skills of students.

Most of the assessment processes carried out so far are still conventional, namely using paper (paperbased test) [15],[16]. The conventional method is deemed less efficient because it requires more costs in duplicating test questions and answer sheets, and is less effective in the evaluation process [15]. The paper test is less practical in its use. The assessment process cannot be done in real time, students cannot find out the test results directly and quickly, so that students' understanding of concepts cannot be detected immediately. Teachers also experience difficulties in correcting answers and providing feedback to each student [15][16]. So, that the conventional assessment process is less practical than technology-based assessment.

The use of a mobile phone or computer as a media for conducting tests is an effort to familiarize students with technology interaction. The use of electronic tests has spread rapidly in recent years. Electronic-based testing offers direct scoring and feedback, and facilitates the use of individual testing methods [17]. Computer-assisted tests can streamline teacher assessment time, and are able to quickly and accurately diagnose student learning difficulties based on completeness of indicators [18],[19]. With its various advantages, electronic assessment can be a media or way to facilitate a more effective evaluation process.

One of the software that is easily accessible, free to use, simple to operate, and good enough to be developed as a performance evaluation tool in the learning process is Google Form [20]. This software is web-based where everyone can provide answers or responses to quizzes or questionnaires quickly wherever they are with their digital devices. So, it is very suitable to be used as an assessment tool to support digital literacy of students.

Reference for digital literacy assessment of students using technology needs to be done. This is useful for improving the quality of the learning process and readiness for the $21 \mathrm{st}$ century. Instruments for assessing digital literacy skills in an accurate way can be used as an identification effort in learning. The development of digital literacy skills test assessments will be very helpful in learning, especially to detect students' digital literacy skills in the current technological era.

\section{RESEARCH METHOD}

This type of development research used in this study aims to develop a test instrument to identify digital literacy skills in high school physics learning. This study uses an instrument development model by Mardapi [21]. This research was conducted at SMAN 1 Prambanan, Klaten, Central Java with the subject of 30 students of class XI MIPA Program.

The development of the instrument follows the following steps: 1 . The stage of making the instrument includes: (1) determining the objectives of the test, (2) determining the competencies to be tested, (3) determining the materials to be tested, (4) preparing the tests, (5) compile tests according to digital literacy indicators; 2. The test analysis phase includes: (1) validating the items, (2) developing the test items. The testing phase of this test includes: (1) determining the test subject, (2) conducting the trial, (3) analyzing the results of the trial.

The assessment of the validity of the instrument by the experts was analyzed using the Aiken validation index. Aiken validation aims to measure the extent to which the items in the instrument meet the specific objectives of assembling the test items. 


$$
\mathrm{V}=\frac{\sum \mathrm{s}}{\mathrm{n}(\mathrm{c}-1)}
$$

In which $V$ is an index of expert agreement regarding the validity of the items. $s$ is the number given by an expert minus the lowest validity rating. There are many experts. $c$ is the highest validity score. Interpretation of the value of $V$, if the value of $V$ is less than 0.4 it means that the validity is low, if the value is between $0.4-0.8$ it is said that the validity is medium, and if it is more than 0.8 then the validity is high [22].

Analysis of dichotomous items was carried out using the 1 Parameter Logistic Model (1 PL) or the Rasch Model. This model only has one item parameter to show the characteristics of the item, namely the item difficulty level parameter [22]. The specific sample sizes for the $1 \mathrm{PL}$ model range from 30-300. Item analysis was performed using the QUEST program. The item analysis carried out included model fit, item reliability, and item difficulty level. Table 1 shown the syntesis of several articles related to digital literacy.

Table 1. Indicators of digital literacy skill

\begin{tabular}{|l|l|l|}
\hline No. & $\begin{array}{l}\text { Aspects of } \\
\text { digital } \\
\text { literacy skill }\end{array}$ & $\begin{array}{l}\text { Indicators of digital } \\
\text { literacy skill }\end{array}$ \\
\hline 1. & Information & $\begin{array}{l}\text { Searching for digital } \\
\text { information }\end{array}$ \\
\cline { 3 - 3 } & $\begin{array}{l}\text { Identify digital } \\
\text { information effectively }\end{array}$ \\
\hline 2. & Comunication & $\begin{array}{l}\text { Communicating } \\
\text { information in a digital } \\
\text { environment }\end{array}$ \\
\cline { 3 - 4 } & $\begin{array}{l}\text { Collaborate on } \\
\text { information or knowledge } \\
\text { in a digital environment }\end{array}$ \\
\hline 3. & Media & $\begin{array}{l}\text { Evaluate the correctness } \\
\text { of information from text } \\
\text { or images or sound or } \\
\text { video in a digital } \\
\text { environment }\end{array}$ \\
\hline 4. & $\begin{array}{l}\text { Problem } \\
\text { solving }\end{array}$ & $\begin{array}{l}\text { Solve conceptual } \\
\text { problems through digital } \\
\text { ways }\end{array}$ \\
\hline $\begin{array}{l}\text { Make decision based on } \\
\text { the information about the } \\
\text { most appropriate digital }\end{array}$ \\
\hline
\end{tabular}

\begin{tabular}{|c|c|c|}
\hline & & $\begin{array}{l}\text { devices according to } \\
\text { purpose and needs }\end{array}$ \\
\hline \multirow[t]{2}{*}{5.} & \multirow[t]{2}{*}{ Security } & $\begin{array}{l}\text { protect personal data and } \\
\text { security measures }\end{array}$ \\
\hline & & $\begin{array}{l}\text { use safe and sustainable } \\
\text { applications }\end{array}$ \\
\hline
\end{tabular}

\section{RESULTS AND DISCUSSION}

\subsection{Test Development Results}

The test instrument was developed based on aspect analysis and digital literacy indicators. The specification of the assessment instrument in the form of multiple choices test refers to indicators of digital literacy skills and physics learning materials. A total of 10 questions assisted by Google form were given to students and worked independently. An example of a test item with an indicator of digital literacy skills can be seen in Figure 1.

Figure 2 shown digital literacy question the Google Form. The use of Google form makes it easy to fill in student questions. Students can directly access the Google Form website that has been provided through a digital device (mobile phone or laptop) that is connected to the internet. Students can immediately provide answers on the form that has been given. All responses and answers will be stored quickly and the teacher can easily find out the answers given by students. The use of Google Forms can also be set by giving the processing time so that when the time limit is up, the Google Form is automatically closed and students can no longer work on it. Google forms can also be a medium for students to get used to interacting with technology.

\subsection{The Validation of Items Result}

Validity testing is used to show how accurate the instrument is. The validity test shows the level of test accuracy in measuring the target to be measured [23]. At this stage the assessment instrument is tested for content validity or content validity. The validity of the content relates to the ability of the assessment tool to measure the content it should be. The evaluation of the content validity uses the Aiken validation index for each item.

There are 10 multiple choice items validated by experts. Assessment of digital literacy test instruments is reviewed based on the suitability of the test with indicators, construction, and language. 3 aspects 


\section{Indikator Literasi Digital:}

Membuat keputusan berdasarkan informasi tentang perangkat digital yang paling tepat sesuai dengan tujuan atau kebutuhan

\section{Indikator Soal:}

Disajikan suatu cara dalam menjalankan simulasi fisika, peserta didik diharapkan dapat merancang tahapantahapan yang tepat dalam menjalankan simulasi menggunakan perangkat digital.

\section{Pertanyaan:}

Susi akan melakukan simulasi fisika menggunakan perangkat digitalnya. Langkah-langkah dalam menjalankan simulasi fisika adalah sebagai berikut:

1.Mencatat data hasil simulasi

2.Memilih topik yang sesuai dengan simulasi yang akan dilakukan

3.Menklik tombol play pada simulasi

4.Mengamati simulasi yang ditampilkan

5.Mengubah variabel besaran

Urutan langkah-langkah yang tepat dalam melakukan simulasi fisika adalah...
a. $3-2-5-4-1$
b. $3-2-4-5-1$
c. $2-4-3-1-5$
d. $2-3-5-4-1$
e. $4-2-3-5-1$

Figure 1 Digital literacy question

(subtance, construct, and language) decide whether a physics achievement test is good or not. The subtances aspect must represent the competencies to be assessed, the construction aspect must meet the technical requirements according to the type of instrument used, and the language aspects used must be good, correct and communicative following the level of development of learners [24]. Each test item is assessed based on the three aspects of the assessment. The results of the validation of the items can be seen in Table 2.

Table 2. Results of item analysis expert judgment assessment instrument

\begin{tabular}{|l|l|l|}
\hline Item Number & Aiken $\mathbf{V}$ & Decision \\
\hline 1 & 0.95 & high validity \\
\hline 2 & 0.9 & high validity \\
\hline 3 & 1 & high validity \\
\hline 4 & 0.9 & high validity \\
\hline 5 & 0.9 & high validity \\
\hline 6 & 0.9 & high validity \\
\hline 7 & 0.95 & high validity \\
\hline 8 & 0.95 & high validity \\
\hline 9 & 0.85 & high validity \\
\hline 10 & 1 & high validity \\
\hline
\end{tabular}

In accordance with the provisions of the Aiken $\mathrm{V}$ index, the results of all validity by the assessment of 5 experts on 10 items are of high validity. Valid instruments influence data or information collected in the field [25]. The content validity based on Aiken's V is said to be good with a value of more than 0.80 [26]. Aiken's validity values ranging from items 1 to 10 are in the range 0.8 to 1 . This can be interpreted that all items have good content validity so that each item of the instrument is declared fit for use.

\subsection{Test Results}

\subsubsection{Goodness fit}

Goodness fit testing is carried out on the test as a whole or on each item. In Rasch analysis, the item fit quality model with the model is abbreviated as item fit [27]. It is determined that an item or test is declared fit with the model at the INFIT MNSQ range limit from 0.77 to 1.30 and using INFIT $t$ with a limit of -2.0 to 2.0 then it is obtained items that match the goodness of fit [21]. The assumption of validity in the Rasch model refers to INFIT MNSQ with a value ranging from 0.6 to 1.21 and OUTFIT MNSQ with a value of 0.11 to 1.17 [28]. Table 3 shows the estimated value of INFIT MNSQ of 0.98 with INFIT $t 0.03$ and OUTFIT MNSQ with an estimated value of 0.97 with INFIT $t$ 0.14. The results showed that the overall fit test was used to measure students' digital literacy skills. 
Table 3. Goodness fit and reliability analysis results

\begin{tabular}{|l|l|l|l|}
\hline No. & Parameter & $\begin{array}{l}\text { Item } \\
\text { Estimates }\end{array}$ & $\begin{array}{l}\text { Case } \\
\text { Estimates }\end{array}$ \\
\hline 1. & $\begin{array}{l}\text { INFIT } \\
\text { MNSQ }\end{array}$ & $0.98 \pm 0.03$ & $1.01 \pm 0.09$ \\
\hline 2. & $\begin{array}{l}\text { OUTFIT } \\
\text { MNSQ }\end{array}$ & $0.97 \pm 0.14$ & $0.97 \pm 0.17$ \\
\hline 3. & $\begin{array}{l}\text { Reliability } \\
\text { estimates }\end{array}$ & 0.80 & \\
\hline
\end{tabular}

Table 3 also shown the reliability estimates with a value of 0.80 . Reliability is one of the requirements for the instrument to be said to be feasible and can be used for measurements in field trials [24]. Reliability is adequate. The instrument has sufficient strength and reliability because it consists of items that have a high information function [29].

\subsubsection{Difficulty levels of items}

The difficulty level or difficulty on each item can be seen in the difficulty level index of the Quest software output shown in Figure 3.

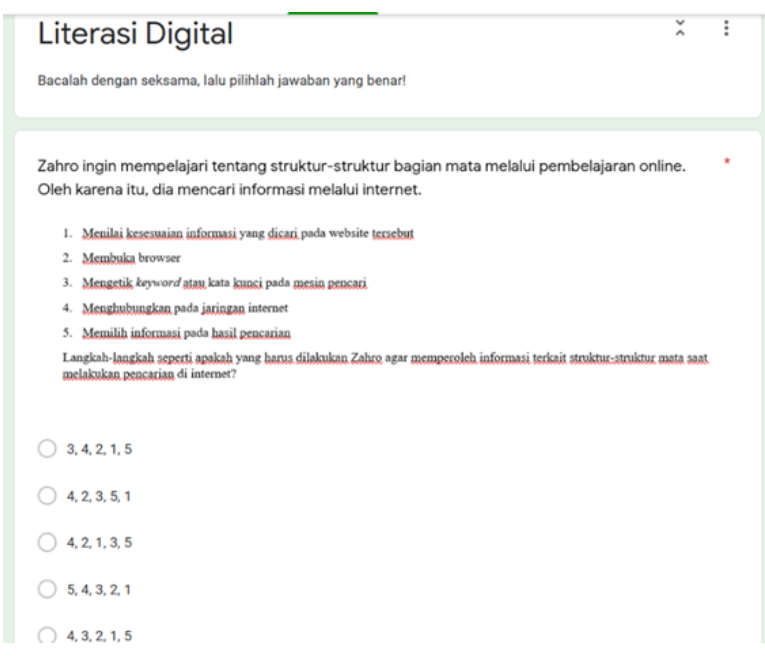

Figure 2 Digital literacy question on the google form

Figure 3 shown the results of the distribution of items with difficulty levels ranging from easy questions to difficult questions. Items with a difficulty level of -2.00 indicate that the item is very easy, while items with a difficulty level of 2.00 indicate that the item is very difficult [30]. Items 5 and 8 have a difficulty level close to +2 which means they have a high difficulty level. Items 2, 3, 4, 6, 9, and 10 are close to 0 which means the question has a medium difficulty. While items 1 and 7 approach -2 indicate that it has an easy level of difficulty.

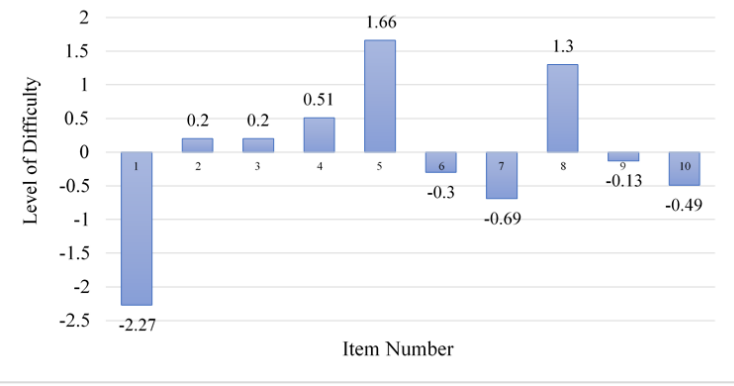

Figure 3 Difficulty level of items

Item is said to be good if the difficulty level is between -2 and $2(-2 \leq b \leq 2)$ [22]. Item 1 has a very low level of difficulty, namely -2.27 , so the item is too easy and not good to use. In items 2, 3, 4, 5, 6, 7, 8, 9, and 10 because they have a difficulty level between -2 and 2 , the items are said to be good and usable.

\section{CONCLUSION}

The test instrument was developed based on aspect analysis and digital literacy indicators. The specification of the assessment instrument in the form of multiple choice test refers to indicators of digital literacy skills and physics learning materials. Total of 10 questions assisted by Google form were given to students. The instrument developed to measure digital literacy skills is declared valid and suitable for use. 10 items were developed, item 1 has a very low level of difficulty so that the item is too easy and not good to use. While the other 9 items have difficulty levels between -2 and 2 which are categorized as good and can be used.

\section{REFERENCES}

[1] Ministry of Education and Culture, The Guide of National Literacy Movement, Jakarta Timur, 2017.

[2] M. Frydenberg, Achieving Digital Literacy Through Game Development: An Authentic Learning Experience, Interaction Technology Smart Education 12(4) (2015) 256-269. DOI: http://dx.doi.org/10.1108/ITSE-08-2015-0022

[3] C.L. Al-Qallaf, A.S.R. Al-Mutairi, Digital Literacy and Digital Content Supports Learning, The Electronic Library 34(3) (2016) 522-547. DOI: $\underline{\text { https://doi.org/10.1108/el-05-2015-0076 }}$

[4] O. Knutsson, M. Blåsjö, S. Hållsten, P. Karlström, Identifying Different Registers of Digital Literacy in Virtual Learning Environments, Internet Higher Education 15(4) 
(2012)

237-246.

DOI:

https://doi.org/10.1016/j.iheduc.2011.11.002

[5] C. McGuinness, C. Fulton, Digital Literacy in Higher Foundation: A Case Study of Student Engagement with E-Tutorials using Blended Learning, Journal Information Technology Education 18 (2019) 1-28. DOI: https://doi.org/https://doi.org/10.28945/4190

[6] S.C. Kong, Developing Information Literacy and Critical Thinking Skills through Domain Knowledge Learning in Digital Classrooms: An Experience of Practicing Flipped Classroom Strategy, Computer Education 78 (2014) 160173.

DOI: https://doi.org/10.1016/j.compedu.2014.05.009

[7] T. Bekker, S. Bakker, I. Douma, J. van der Poel, K. Scheltenaar, Teaching Children Digital Literacy through Design-Based Learning with Digital Toolkits in Schools, International Journal Child-Computer Interaction 5 (2015) 29-38. DOI: https://doi.org/10.1016/j.ijcci.2015.12.001

[8] J. Fraillon, J. Ainley, W. Schulz, D. Duckworth, T. Friedman, IEA international computer and information literacy study 2018 assessment framework, Springer, Berlin, Heidelberg, 2019. DOI: https://doi.org/10.1007/978-3-030-19389-8

[9] K. Chetty, L. Qigui, N. Gcora, J. Josie, L. Wenwei, Bridging The Digital Divide: Measuring Digital Literacy, Economics: The Open-Access, Open-Assessment E-Journal 12 (2018) 1-20. DOI: http://dx.doi.org/10.5018/economicsejournal.ja.2 018-23 Bridging

[10] V. Herlina, G. Yarmi, S.R. Yuliati, Pengembangan Buku Cerita Anak Digital Berbasis Literasi Digital pada Siswa Kelas V Sekolah Dasar, Dinamika Sekolah Dasar (2019) $1-13$.

[11] D. Rahmawan, J.N. Mahameruaji, R. Anisa, Pengembangan Konten Positif Sebagai Bagian dari Gerakan Literasi Digital, Jurnal Kajian Komunikai 7(1) (2019) 31-43. DOI: https://doi.org/10.24198/jkk.v7i1.20575

[12] E.P. Widoyoko, Evaluasi Program Pembelajaran: Panduan Praktis Bagi Pendidik dan Calon Pendidik, Pustaka Belajar, 2016.

[13] Z. Arifin, Evaluasi Pembelajaran: Prinsip, Teknik, dan Prosedur, PT. Remaja Rosdakarya, 2017.
[14] Ikhsanuddin, Konstruksi Tes Formatif Untuk Diagnosis Miskonsepsi Materi Biologi SMA Kelas X Semester Gasal, ePrints, Universitas Negeri Yogyakarta (UNY), 2018.

[15] H. Sahidu, G. Gunawan, I. Indriaturrahmi, F. Astutik, Desain Sistem e-assessment pada Pembelajaran Fisika di LPTK, Journal Pendidikan Fisika dan Teknologi 3(2) (2017) 265. DOI: https://doi.org/10.29303/jpft.v3i2.422

[16] A. Sarasvati, Pengembangan Science Assesment Website ( $\mathrm{Sc}-\mathrm{Wb}$ ) Tema Sistem Ekskresi Manusia untuk Kelas VIII SMP, Universitas Negeri Semarang, 2016.

[17] H. Jeong, A Comparative Study of Scores on Computer-Based Tests and Paper-Based Tests, Behaviour \& Information Technology 33(4) (2014) 37-41. DOI: https://doi.org/10.1080/0144929X.2012.710647

[18] U. Maier, N. Wolf, C. Randler, Effects of A Computer-Assisted Formative Assessment Intervention Based On Multiple-Tier Diagnostic Items and Different Feedback Types, Computer Education 95 (2016) 85-98. DOI: https://doi.org/10.1016/j.compedu.2015.12.002

[19] V.M. Salma, Pengembangan e-diagnostic Test untuk Mengidentifikasi Pemahaman Konsep Fisika Siswa SMA pada Pokok Bahasan Fluida Statis, Unnes Physics Education Journal (UPEJ) 5(1) (2016). DOI: https://doi.org/10.15294/upej.v5i1.12701

[20] H.H. Batubara, Penggunaan Google Form sebagai Alat Penilaian Kinerja Dosen di Prodi PGMI UNISKA Muhammad Arsyad Al-Banjari, Al-Bidayah Jurnal Pendidikan Dasar Islam 8(1) (2016) 40-50. DOI: https://doi.org/10.14421/albidayah.v8i1.91

[21] D. Mardapi, Pengukuran Penilaian dan Evaluasi Pendidikan, Parama Publishing, 2008.

[22] E. Istiyono, Pengembangan Instrumen Penilaian dan Analisis Hasil Belajar Fisika, Universitas Negeri Yogyakarta (UNY) Press, 2018.

[23] T.P. Siregar, E. Surya, E. Syahputra, Quality Analysis of Multiple Choice Test and Clasical Test at X Grade Students of Senior High School, Journal IJARIIE Universitas Medan 3(2) (2017) 2153-2159.

[24] Supahar, Applying content validity ratios (CVR) to the quantitative content validity of 
physicslearning achievement tests, in: Proceedings of The $5^{\text {th }}$ International Conference on Research, Implementation and Education of Mathematics and Sciences (ICRIEMS), FMIPA UNY, Yogyakarta, 2015, pp. 17-19.

[25] F. Kurnia, D. Rosana, Supahar, Developing evaluation instrument based on CIPP models on the implementation of portfolio assessment, in: AIP Conference Proceedings, vol. 12, no 9, AIP Publishing, College Park, Maryland, 2017, pp. 1999-10.

DOI: https://doi.org/10.1063/1.4995187

[26] S. Azwar, Penyusunan Skala Psikologi Edisi Kedua, Pustaka Belajar, 2017.

[27] S. Nuryanti, M. Masykuri, E. Susilowati, Analisis Iteman dan Model Rasch pada Pengembangan Instrumen Kemampuan Berpikir Kritis Peserta Didik Sekolah Menengah Kejuruan, Jurnal Inovasi Pendidikan 4(2) (2018) 224-233. DOI: https://doi.org/10.21831/jipi.v4i2.21442

[28] C.Y. Huang, L.C. Tung, Y.T. Chou, W. Chou, K.L. Chen, C.L. Hsieh, Improving The Utility of The Fine Motor Skills Subscale of The Comprehensive Developmental Inventory for Infants and Toddlers: A Computerized Adaptive Test, Disability Rehability 40(23) (2018) 28032809.

DOI: https://doi.org/10.1080/09638288.2017.1356385

[29] A.T.Y. Nadapdap, E. Istiyono, Developing Physics Problem-Solving Skill Test for Grade X Students of Senior High School, REiD (Research Evaluation Education) 3(2) (2017) 114-123. DOI: https://doi.org/10.21831/reid.v3i2.14982

[30] E. Istiyono, D. Mardapi, S. Suparno, Pengembangan Tes Kemampuan Berpikir Tingkat Tinggi Fisika (PysTHOTS) Peserta Didik SMA, Jurnal Penelitan dan Evaluasi Pendidikan 18(1) (2014) 1-12. DOI: https://doi.org/10.21831/pep.v18i1.2120 